\title{
GIS in the Assessment of the Impact of Microclimatic Variables on Human Comfort in Akure, Nigeria.
}

\author{
Alaigba, D. B., Fabiyi, O. O. and Akinnawo, O. S. \\ Regional Centre for Training in Aerospace Surveys (RECTAS), Ile-Ife, Osun State, Nigeria. \\ Email Address: deborahalaigba@gmail.com \\ Phone Number: +234 8035367146
}

DOI: http://dx.doi.org/10.4314/sajg.v7i1.5

\begin{abstract}
This study involved the use of Geographic Information System (GIS) to examine variation of physiologic comfort of the people living in Akure urban environment using physiological equivalent temperature (PET) index. PET value generated from both micro-climatic parameters and thermophysiological data measured, using Rayman model because of its ability to generate mean radiant temperature and PET which is useful in thermo-physiological heat balance model. It also examines the responses from sampled population across the land uses. Results showed that thermal heat stress are found spatially and temporally (6:00; 12:00 and 18:00 local standard time, LST) within the study area as high as (41-55) ${ }^{\circ} \mathrm{C}$ due to different activities in each of the land uses. Results indicated that many of the respondents are yet to have better understanding about thermal stress and it effects. The recommendation from this study is that more days of data should be measured during dry season, and planting of tress and urban greenery should be strongly encouraged as a means to improve the micro climate as well as the level of human comfort in Akure, Nigeria.
\end{abstract}

Keywords: Micro-climate, Urbanization, Thermal comfort, PET, Rayman.

\section{Introduction}

The effect of the climatic variability can be seen on human well-being, health and environment (Adakayi, 2009) which makes the comfort of human as a phenomenon both spatial and temporal. The most important climate of any urban environment is microclimatic conditions, which differ significantly from that of rural areas. Micro-climate can be described as the climate at small spatial and temporal scales of any biological environment (Shaibu and Utang, 2013).

Ndetto and Matzarakis (2013) suggested that better understanding of urban microclimate and bioclimatic condition of any city requires urgent attention today, as a result of the constraints by urbanization and global climate change. Studies show that the world is experiencing rapid urbanisation, with $45 \%$ of all the population already living in urban areas as of year 2000 (Arnfield 2003). Urban is defined as an environment where the density of population and economic activities are more than in other places with higher rate of destruction of natural resources (Toy et al., 2007). Evidence has shown that anthropogenic heat emission at various land use is a major factor contributing to heat island (Ohashi et al., 2007). With higher rate of economic development, 
urbanization coupled with population growth continue in developing countries, anthropogenic heat increases as well (Ichinose and Bai, 2000). Akure is not exempted from this as the population and economic activities have increased and more than tripled from 1990- 2006 (Ogunsote, 2007; Balogun et al., 2011).

There is mutual relationship between man and climate that man responds to variation in climate by insulating buildings, heating and air-conditioning. The aim of any man is to be comfortable despite the climate, and this gives rise to the belief of thermal comfort (Eludoyin et al., 2013). Outside comfort zone lies the thermal stress (Ogunsote and Prucnal-Ogunsote, 2007). Thermal comfort can be expressed with the six basic parameters, two of these parameters are personal parameters (cloth and activity levels) and the others are environmental parameters (air temperature, wind speed, relative humidity and mean radiant temperature) (Matzarakis et al., 2007).

During the last decade, interest in the assessment of urban thermal comfort has increased because of climate changes and increased heat stress in cities. But there have been relatively small numbers of studies on thermal comfort for outdoor environment (Swaid et al., 1993; Nikolopoulou et al., 2001; Givoni et al., 2003; Spagnolo \& de Dear 2003). A good number of indices have been developed to accurately estimate thermal comfort in urban environment. Indices such as standard Effective Temperatures (SET), Predicted Mean Vote (PMV) and physiological equivalent temperature (PET) are the most broadly used as outdoor comfort indices (Givoni et al., 2003). However, for this study PET will be considered because of its ability to care for the diversity of outdoor climatic settings; it will be implemented using RayMan model which include the inputs of meteorological parameters with thermo-physiological parameters which are; human activity level and cloth value (Matzarakis et al., 2007).

By utilizing and implementing GIS mapping techniques, changes in urban thermal comfort can be monitored and mapped for developmental projects (Rahman et al., 2009), as the Urban and regional planners are demanding easily understandable methods to facilitate comfortable urban microclimates. The importance of this paper lies in examining the human comfort of people in Akure, a city in Nigeria, based on bioclimatic and urban climate studies of the area, demonstrating the quantitative evaluation of human comfort and heat stress within the study area by the measurement of microclimate parameters.

\section{Description of the study area}

Akure is a city in Nigeria and the administrative headquarter of Ondo state in western Nigeria since 1976, located between longitudes 5 ${ }^{\circ}{ }^{\prime} 00^{\prime} \mathrm{E}$ and $5^{\circ} 15^{\prime} 00^{\prime \prime} \mathrm{E}$ and latitudes $7^{\circ} 10^{\prime} 00^{\prime \prime} \mathrm{N}$ and $7^{\circ} 17^{\prime} 00^{\prime \prime} \mathrm{N}$ with an altitude of about 370 meters above sea level. The hilly and studded land with granite formations was believed to be of volcanic origin spreading over large areas (Ogunsote, 2007). Akure city is one of the fast-growing cities in the south-west with population growth tripling in value from the population recorded in the year 1999; 157,947 to about 500,000 in the year 2006 (Ogunsote, 2007; Balogun et al., 2011). 


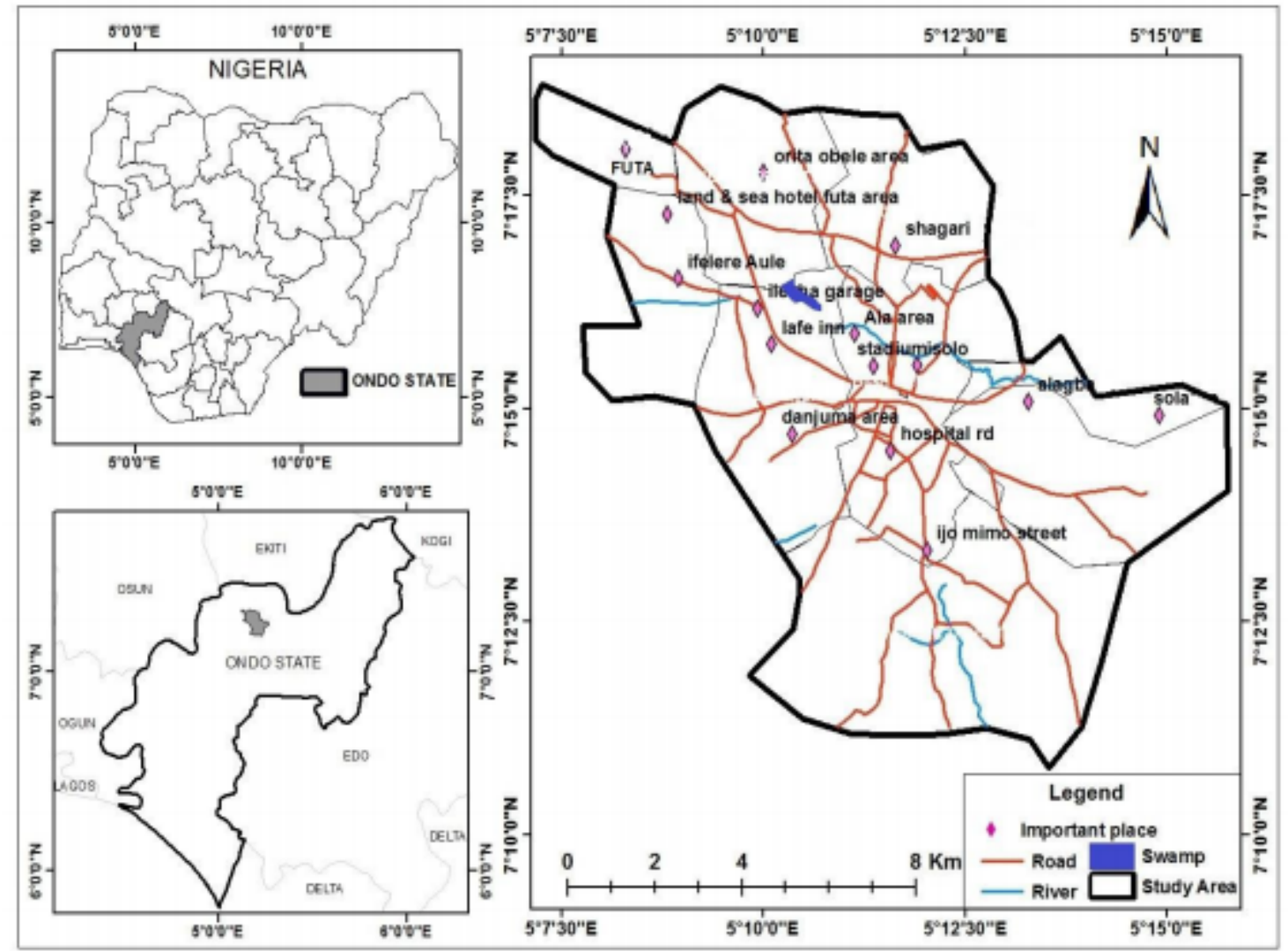

Figure 1: Maps showing the study area in Ondo State (right) and Ondo State in Nigeria (left)

Climatically, Ondo state has humid tropical climate and belongs to the equatorial rain forest belts. The climate of the study area is classified as tropical wet and dry season. Characteristically, wet season ranges between April to October and dry season ranges between November and March. Akure maintains moderately warm humid tropical climate with high temperature, maximum temperature of about $86^{\circ} \mathrm{F}$ and minimum stand at about $71.6^{\circ} \mathrm{F}$ with an average daily temperature of $93.2^{\circ} \mathrm{F}$. Rainfall is averagely about $1524 \mathrm{~mm}$ per year (Ogunsote, 2007).

\section{Materials and Methods}

\subsection{Kestrel weather Meter 3000}

A physical measurement of micro-climatic parameters that influences human energy balance was carried out. The parameters were measured using a hand-held weather meter instrument by Kestrel “3000” series with Global Positioning system (Garmin GPS etrex 30) of \pm 2.0 meter used to record coordinate of the points at the height $1.1 \mathrm{~m}$ above ground level. The instrument was calibrated and tested with the following specifications; Temperature measurement range $-29{ }^{\circ} \mathrm{C}-70{ }^{\circ} \mathrm{C}$ with the accuracy of $\pm 0.5^{\circ} \mathrm{C}$, Relative humidity measurement range $5 \%$ - 95\% with accuracy; \pm 3.0 and Wind speed measurement range $0.6-40.0 \mathrm{~m} / \mathrm{s}$, with accuracy of \pm 0.1 .

All the field surveys were performed on days of dry season of the year, In order to account for change in daily climatic conditions, the field survey was conducted in three sections a day (morning (6:00), midday (12:00) and evening (18:00) local time) for five days in different delineated land use types as shown in figure 2: and the average of each section were obtained as shown in table 2 below. 
Data collection was based on participatory approach in a field survey. Olanipekun (2014) argued that field surveys are the only way through which comfort standards can be realistically related to people's needs among acclimatized populations. This is to say that the people in the field survey will act as "meters" of their environment. Different site was visited to obtain different perspective view of the people concerning outdoor human thermal comfort in Akure urban area such as commercial, institutional (tertiary), residential, and administrative area among others. Composite sampling method was thus adopted by taking the readings in different days at the same points.

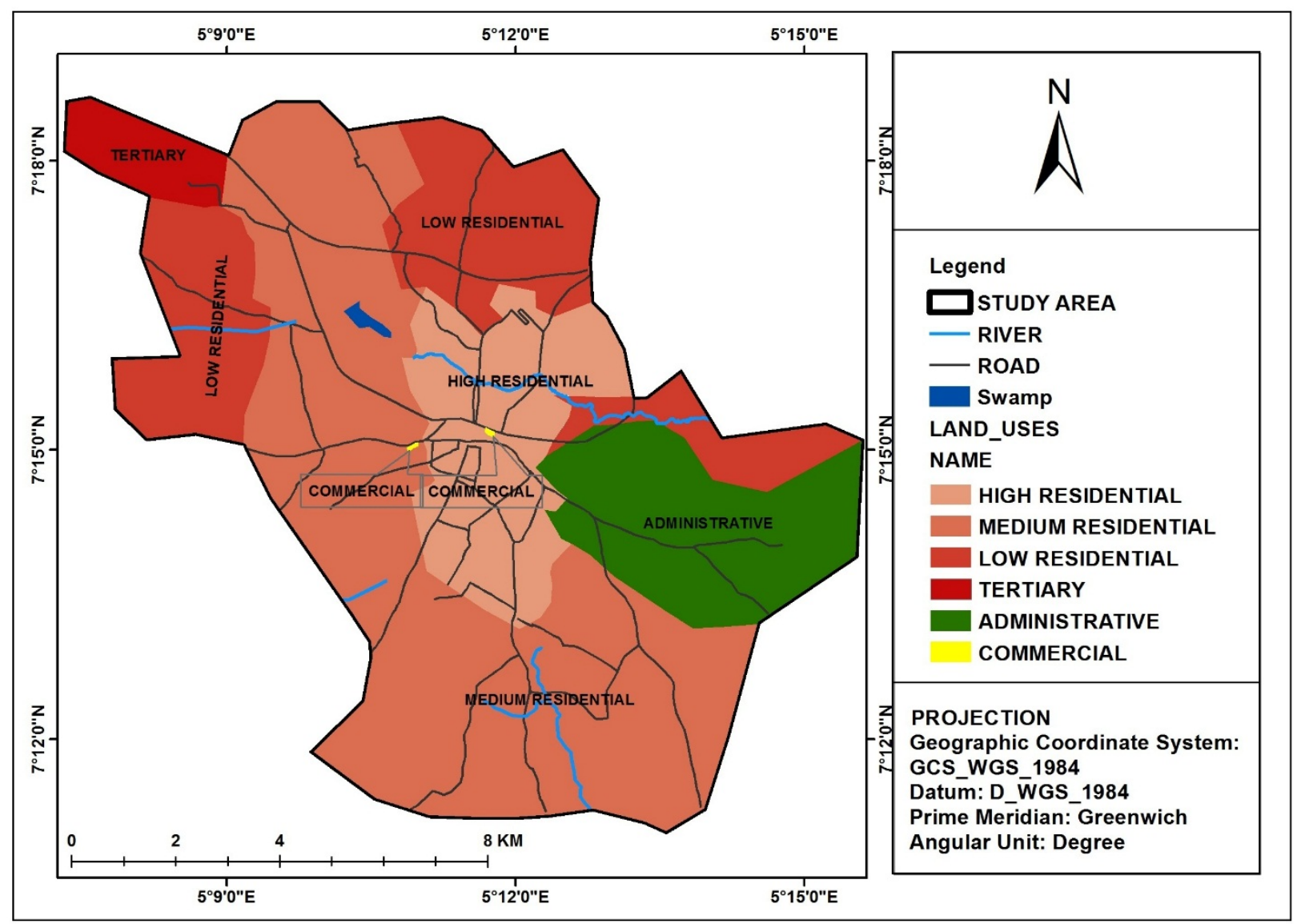

Figure 2: Map showing land use types within the study area

A total of 200 valid copies questionnaire were administered to different people in different land uses visited and only 186 copies questionnaires were collected back during the study period. To determine the sampled population, Slovin’s formula (Edward \& Johnny, 2015) was used:

$$
n=N /\left(1+N e^{2}\right)
$$

Where $n$ equals number of samples, $N$ equals total population targeted and $e$ equals error margin. Slovin's formula is usually used when there is no knowledge about the total population of the study area. A total of 1000 population were targeted at the margin error of $6.3 \%$ at the confidence level of 93.7\%. Studies shows that the responses from a tertiary institution could sometimes be stronger than that of any other area in an urban settlement with the probability that those in schools are likely to be more conscious and inquisitive than others within any study community (Eludoyin, 2014). 
The participatory assessment was based on responses to a questionnaire survey, which was administered simultaneously with physical measurement during each survey. The scope of the questionnaire was based on several preceding studies, and conformed to ASHRAE standard questionnaire for indoor thermal comfort study (ASHRAE, 2010). Rayman model, developed in Meteorological Institution, University of Frieburg, Germany according to the guide line of German Engineer Society to evaluate thermal component of urban climate. A very useful model which is used to calculate values of mean radiant temperature and PET (Agnes et al., 2005, Chirag and Ramachandraiah, 2011, Akinyemi et al., 2012).

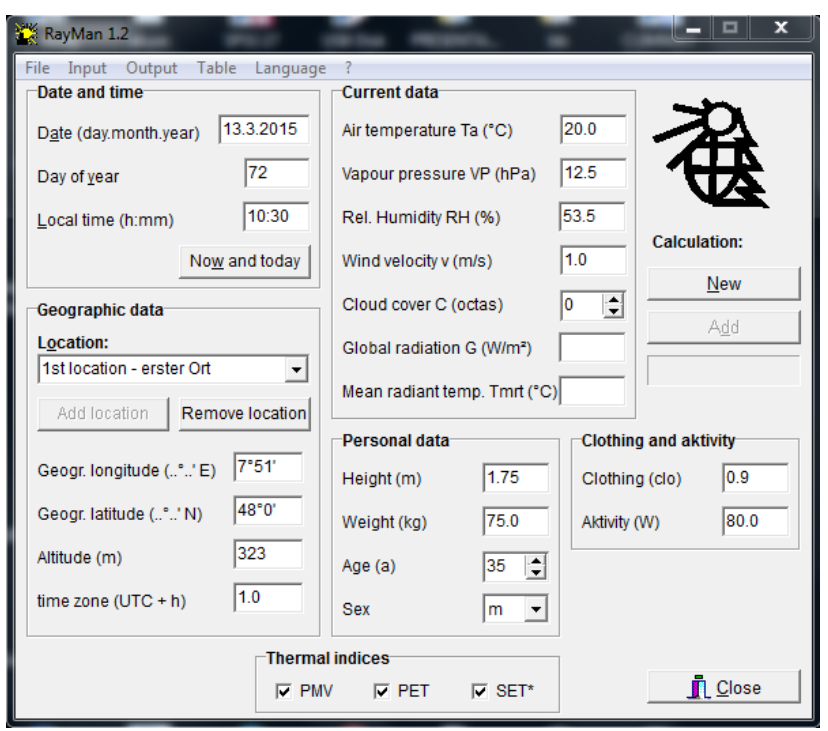

Figure 3: RayMan Model User Interface

The spatial distribution of the generated PET values in the different land use types was then visualized. The Physiologically Equivalent Temperature (PET) was adopted for this study because of its appropriateness to the law that govern the thermal comfort and inclusion of both meteorological and non-meteorological parameters in its calculation by the Ryman model (Matzarakis et al., 2007).

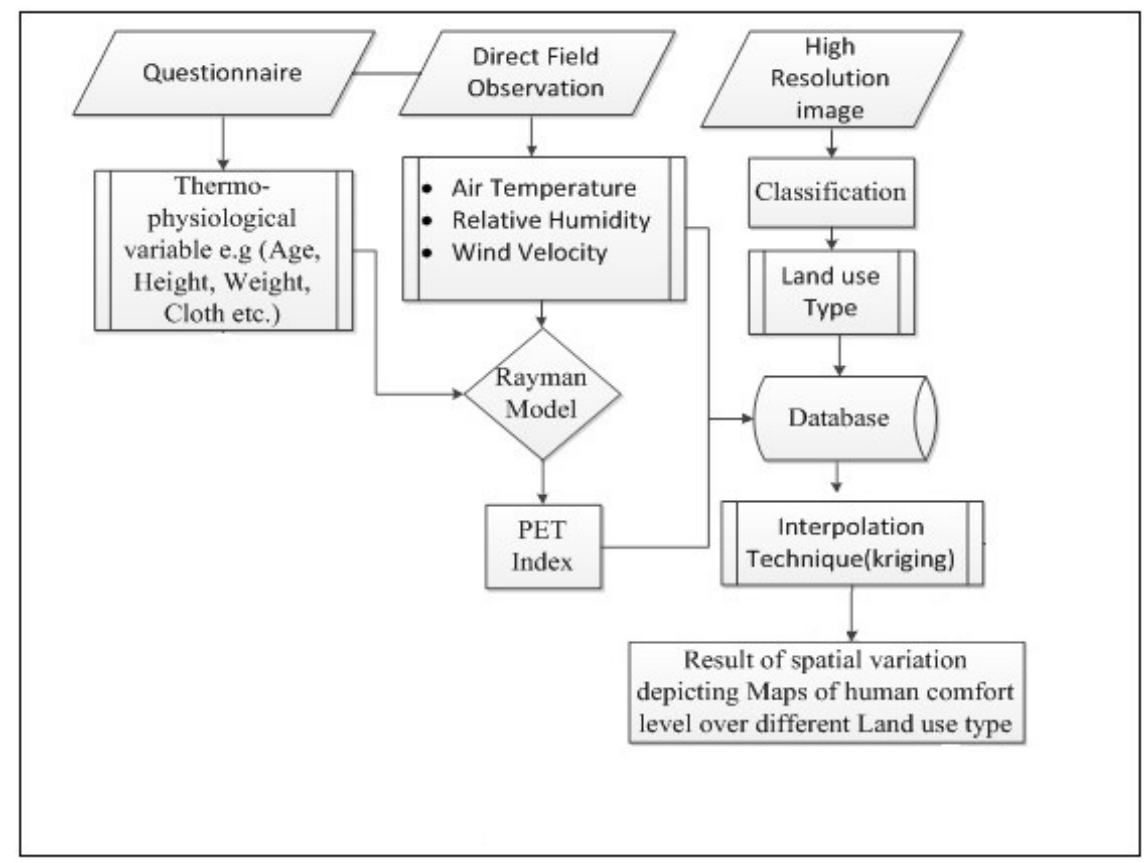


Figure 4: Methodology Flow Diagram

Respondents who were sitting and standing with low physical activities were included during the survey, the metabolic rate was taken to be 1.2 met and 1.4 met using ASHRAE, 2010 standard for sitting and standing respondents respectively $\left(1 \mathrm{met}=58.15 \mathrm{~W} / \mathrm{m}^{2}\right)$ according to "cloth value" during the study period which was rated as 0.66 clo as a result of the season. The average values of data directly observed from the field were processed in Rayman model to generate PET values, which was integrated into geo-database as shown in Figure 4 above. Kriging interpolation method (Geostatistical analysis) was used, being the best interpolation technique for temperature as proved by literature (Gulyás and Matzarakis, 2007). Interpolated values classified were compared to match the PET index value for Nigeria Climate (Omonijo and Matzarakis, 2011).

Table 1: Physiological Equivalent Temperature (PET) in Nigeria

\begin{tabular}{|c|c|c|c|}
\hline $\begin{array}{l}\text { PET Range for } \\
\text { Nigeria }\end{array}$ & $\begin{array}{l}\text { Thermal } \\
\text { Sensation }\end{array}$ & $\begin{array}{l}\text { Grade of Physiological } \\
\text { Stress }\end{array}$ & $\begin{array}{l}\text { PET Range for } \\
\text { western/Central } \\
\text { Europe }\end{array}$ \\
\hline$\leq 11$ & Very cold & Extreme cold stress & $\leq 4$ \\
\hline$>11 \leq 15$ & Cold & Strong cold stress & $4 \leq 8$ \\
\hline$>15 \leq 19$ & Cool & Moderate cold stress & $8 \leq 13$ \\
\hline$>19 \leq 23$ & Slightly cool & Slight cold stress & $13 \leq 18$ \\
\hline$>23 \leq 27$ & Neutral & No thermal stress & $18 \leq 23$ \\
\hline$>27 \leq 31$ & Slight warm & Slight heat stress & $23 \leq 29$ \\
\hline$>31 \leq 36$ & warm & Moderate heat stress & $29 \leq 35$ \\
\hline$>36 \leq 42$ & Hot & Strong heat stress & $35 \leq 41$ \\
\hline$>42$ & Very hot & Extreme heat stress & $>41$ \\
\hline
\end{tabular}

\section{Results and Discussion}

\section{Average value of Microclimatic Parameters}

Table 2: Statistical Summary

\begin{tabular}{ccccc}
\hline & Min & Max & Mean & SD \\
\hline Air temperature $\left({ }^{\circ} \mathbf{C}\right)$ & 25.41 & 34.19 & 30.07 & 2.55 \\
\hline Relative humidity (\%) & 53.82 & 88.27 & 67.35 & 10.61 \\
\hline Wind speed (m/s) & 0.71 & 0.78 & 0.76 & 0.02 \\
\hline
\end{tabular}

On survey days, the weather was clear with a continuous strong sunshine, temperature values increased quickly all through the survey days, minimum, maximum and mean temperature in the study area based on five days field survey were $25.41^{\circ} \mathrm{C}, 34.19^{\circ} \mathrm{C}$ and $30.07^{\circ} \mathrm{C}$, respectively. The temperature measured are identical in every surveyed points $(25.41-25.60){ }^{\circ} \mathrm{C}$ in the morning 
sections, which was also observed in the noon and evening survey section. From table 2, the minimum, maximum and mean relative humidity for the whole study was given as $53.82 \%, 88.27 \%$ and $67.35 \%$ respectively. The speed of the wind recorded directly was $0.71 \mathrm{~m} / \mathrm{s}$ minimum value, 0.78 maximum value and mean value of $0.76 \mathrm{~m} / \mathrm{s}$ respectively. In general, the standard deviation for the measured parameters are low, this indicates that the parameters measured were homogeneous and uniform during the study period.

\section{Variation of Human Comfort Index in different Land Use Types}

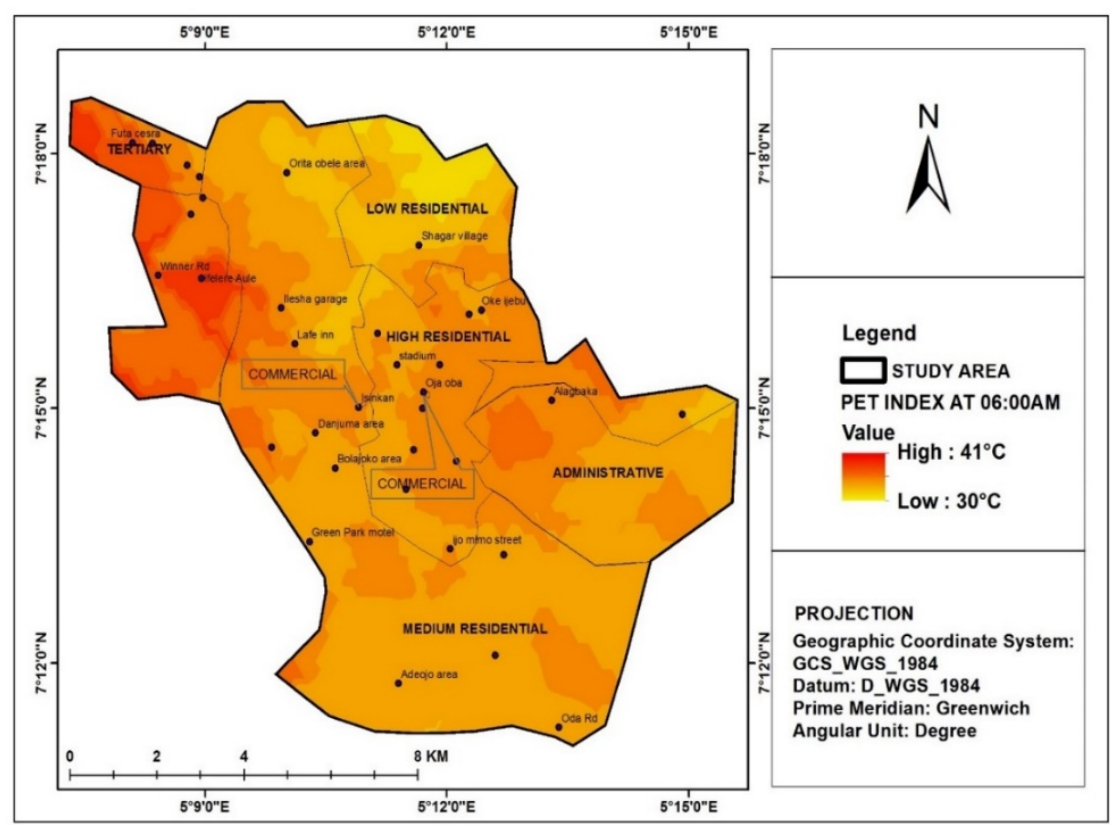

Figure 5: Physiological Equivalent Temperature (PET Index) of Akure at 6:00hr

Figure 5 shows the result of PET index obtained in the early hour of 6:00am local time from the average value of 5 days survey. The lowest PET value was $30^{\circ} \mathrm{C}$ and the highest value was $41^{\circ} \mathrm{C}$. In comparison with the PET range for Nigeria condition as proposed by Omonijo and Matzarakis (2011), the PET values obtained lies within the slightly warm and hot thermal sensation. It indicates that the people in the area of study are thermally uncomfortable, that is, they are living above the standard and acceptable thermal comfort level. 


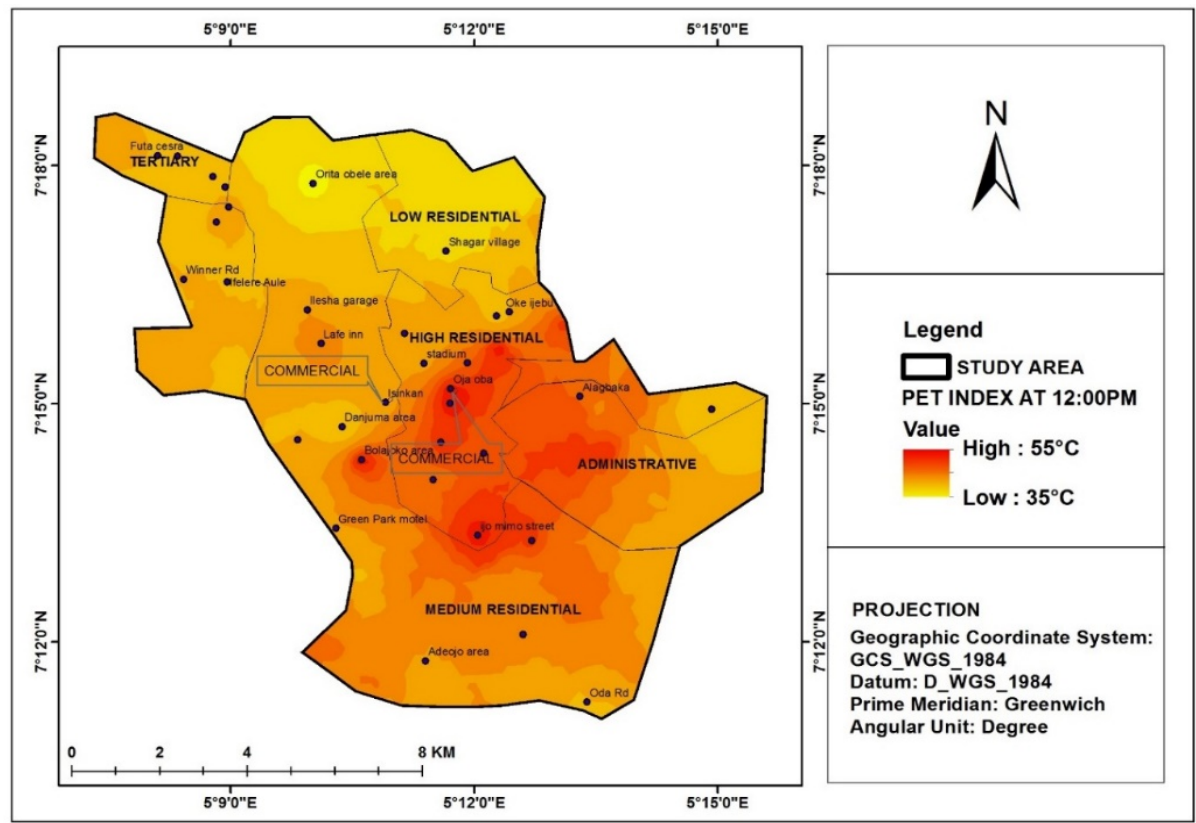

Figure 6: Physiological Equivalent Temperature (PET Index) of Akure at 12:00hr

The map in Figure 6 represents mean daily (noon) value of PET based on the parameters of air temperature, relative humidity, wind speed, activities and cloth value. During the period of study, the thermal comfort condition $\left(35^{\circ} \mathrm{C}-55^{\circ} \mathrm{C}\right)$ were observed at the hour of 12:00hr. The legend showed that the thermal environment during the study period of the hour was above extreme heat stress, with the concentration of the stress found in high residential area of the urban centre.

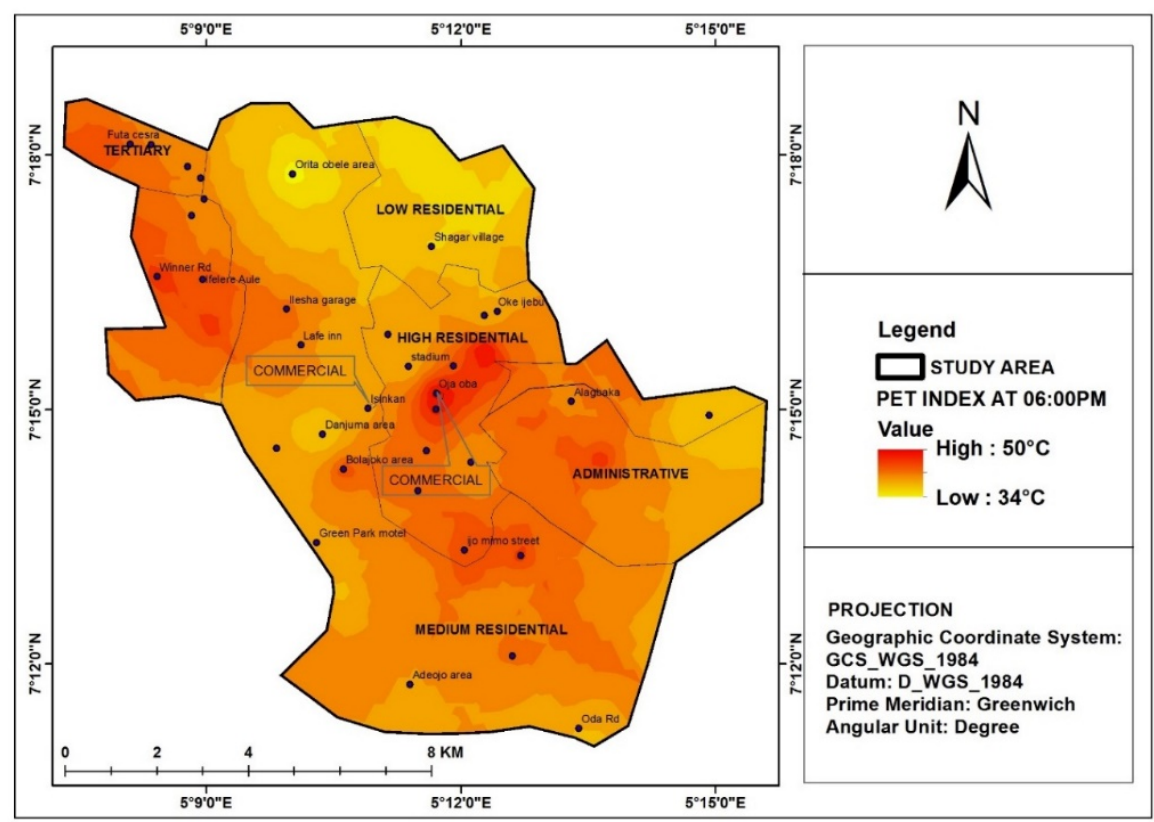

Figure 7: Physiological Equivalent Temperature (PET Index) of Akure at 18:00hr

From the result in Figure 7, the evening thermal condition of the environment took another dimension. The PET values obtained were found to be $\left(34-50^{\circ} \mathrm{C}\right)$, when compared with Nigeria PET range, it lies within the warm and very hot thermal sensation (moderate heat stress and extreme heat stress). 
In summary, the results in Figures 5 - 7 shows that there were shifts in the PET values at different land uses, at 6:00hr all through the surveyed days, the stress was found in the tertiary area and it environ of the land uses. There was a shift during the noon section 12:00hr, as the stress was moved to commercial area, this area are known to engage in heavy activities with few or no trees around the different structures, pavement and tiled environment. According to the generated PET values, heat stress is experienced on the surveyed days with the highest value of $55^{\circ} \mathrm{C}$ showing an extreme heat stress in table 1. Low residential area and its environs, has the lowest values of PET, this was also observed during the direct visit and measurement, to the sites which is caused presumably by tress (shield direct sunshine) and high wind speed (coolant).

Similar to the result of Omonijo \& Matzarakis (2011) in their study of climate and bio-climate analysis of Ondo state (1998-2008), recorded high PET values in the transition period to dry season. Their result showed similar, high daily PET values observed in the derived savannah (Akure inclusive) ranging from $\left(26.5^{\circ} \mathrm{C}-42.2^{\circ} \mathrm{C}\right)$. Balogun \& Balogun (2014), also obervsed heat stress in their study on Urban heat island and bioclimatological conditions in a hot humid tropical city in Akure, has more very hot and torrid afternoon. when most of the people feel discomfort, where urban heat island has its maximum occurrence at night between 18:00 and 22:00 local time despite the fact that thermohydrometric index (humidex index) was used.

\section{Conclusion and Recommendation}

High rate of heat stress has effect on the environment and on the health of people thereby leading to heat related diseases such as fatigue, sunstroke, muscle cramps, heat stroke and heat exhaustion. The result from this study showed that in general Akure is rather uncomfortable, providing useful information for planners and decision makers in planning new urban environment. Futher studies is recommended in the area of similar surveys to be carried out during the dry season of the year. Also adequate awareness of heat stress and it related problem should be made known to people in Akure. Urban greenery and planting of tress within the city space is strongly recommended for Akure, Nigeria.

\section{References}

Adakayi, P. E. 2009. Temperature Trends over Katsina. The Abuja Journal of Geography and Development, 3, 97-106.

Akinyemi, G. O., Clement, O. A., Olusegun , O. \& Andreas , M., 2012. Relevance of thermal environment to human health: a case study of Ondo State, Nigeria. Journal Theoretical Applied Climatology, 2013 (113), 205-212.

Arnfield, A. J. 2003: Two decades of urban climate research: a review of turbulence, exchanges of energy and water, and the urban heat island. - International Journal of Climatology 23 (1), 1-26.

ASHRAE 2010. Thermal environmental conditions for human occupancy. ASHRAE standard; American Society of Heating, Refrigerating and Air-Conditioning Engineers. Atlanta: ASHRAE. 
Balogun, I. A. \& Balogun, A. A. 2014. Urban Heat Island and Bioclimatological Conditions in a hot-humid Tropical city: the example of Akure. Journal Geographical Society of Berlin, 145, 1-113.

Balogun, I. A., Adeyewa, Z. D. \& Balogun, A. A. 2011. Analysis of urban expansion and land use changes in Akure, Nigeria, using remote sensing and geographic information system (GIS) techniques. ournal of Geo-graphy and Regional Planning, 4, 533-541.

Chirag, D. \& Ramachandraiah, A., 2011. A simple technique to classify urban locations with respect to human thermal comfort: Proposing the HXG scale. Journal of Building and Environment, 46(2011), 1321 $-1328$.

Edward , B. A. \& Johnny, B. E., 2015. Applied Survey Sampling. first ed. Thousand Oaks, CA: SAGE publications Inc.

Eludoyin, M. O. 2014. A Perspective of the Diurnal Aspect of Thermal Comfort in Nigeria. Atmospheric and Climate Sciences, 4, 696-709.

Eludoyin, O. M., Adelekan, I. O., Webster, R. \& Eludoyin, A. O. 2013. Airtemperature, relative humidity, climate regionalization and thermal comfort of Nigeria. International Journal of Climatology, 86, 1-19.

Gulyás, A. \& Matzarakis, A. 2007. Selected Examples of Bioclimatic Analysis Applying the Physiologically Equivalent Temperature in Hungary. Journal of climatology and meteorology, 25, 3746.

Gulyás, Á., Unger, J. \& Matzarakis, A. 2006. Assessment of the microclimatic and human comfort conditions in a complex urban environment: Modelling and measurements. Building and Environment, 41(12), 1713-1722.

Givoni, B., Noguchi, M., Saaroni, H., Pochter, O., Yaacov, Y., Feller, N. \& Becker, S. 2003. Outdoor comfort research issues. Energy and Buildings, 35, 77-86.

Ichinose, T. \& BAI, Y. 2000. Anthropogenic heat emission in Shanghai City. Proceedings of Annual Meeting of Environmental Systems Research, 28, 329-337.

Ifatimehin, O. O., Adeyemi, J. O. \& Saliu, A. O. 2013. The impact of Urban Micro-climate change on human comfort in Lokoja. Kastina journal of Natural and Applied Sciences, 3, 93-104.

Matzarakis, A., Rutz, F. \& Mayer, H. 2007. Modelling radiation fluxes in simple and complex environments - application of the RayMan model. International Journal of Biometeorology, 51, 323-334.

Mayer, H. \& Höppe, P. 1987. Thermal comfort of man in different urban environments. Theor. Appl. Climatol, 38, 43-49.

Ndetto, E. \& Matzarakis, A. 2013. Basic analysis of climate and urban bioclimate of Dar es Salaam, Tanzania. Theoretical and Applied Climatology, 114, 213-226.

Nikolopoulou, M., Baker , N. \& Steemers, K. 2001. Thermal comfort in outdoor urban spaces: understanding the human. Solar Energy, 70, 227-235.

Ogunsote, O. O. \& Prucnal-Ogunsote, B. Extreme Weather and Climate Events: Implications for Urban Planning, Architecture and Tourism Infrastructure in Nigeria. 2007 Akure. Futa.

Ogunsote, O. O. 2007. Climate Data of Akure for the year 1998. Akure: FUTA PRESS.

Ohashi, Y., Genchi, Y. \& Kondo, H. 2007. Influence of air-conditioning waste heat on air temperature in Tokyo during summer: numerical experiments using an urban canopy model coupled with a building energy model. Journal of Applied Meteorology and Climatology, 46, 66-81. 
Omonijo, A. G. \& Matzarakis, A. 2011. Climate and bioclimate analysis of Ondo State, Nigeria. Meteorologische Zeitschrift, 20, 531-539.

Rahman, A., Netzband, M., Singh, A. \& Mallick, J. 2009. An assessment of urban environmental issues using remote sensing and GIS techniques. An integrated approach; A case study of Delhi, India. In: De Sherbinlin, A., Rahman, A., Barbieri, A., Fotso, J. C. \& Zhu, Y. (eds.) Urban Population-Environment Dynamics in the developing world. Delhi: CICRED.

Shaibu, V. O. \& Utang, P. B. 2013. Human Comfort and the Microclimatic drivers across different land use types in Port Harcourt Metropolis, Nigeria. Ethiopian Journal of Environmental Studies and Management, 6, 737-745.

Spagnolo, J. \& De Dear, R. J. 2003b. A human thermal climatology of subtropical Sydney. International Journal of Climatology, 23, 1383-1395.

Swaid, H., Bar-El, M. \& Hoffman, M. E. 1993. A bioclimatic design methodology for urban outdoor spaces. Theoretical and Applied Climatology, 48, 49-61.

Toy, S., Yilmaz, S. \& Yilmaz, H. 2007: Determination of bioclimatic comfort in three different land uses in the city of Erzurum, Turkey. - Building and Environment 42(3): 1315-1318 